\title{
HAEMATOLOGICAL CHARACTERISTICS OF THE BLOODY COCKLE Anadara senilis (L.) FROM ANDONI FLATS, NIGER DELTA, NIGERIA.
}

\section{GABRIEL, U. U1; *AKINROTIMI, O. A². \& ORLU, E. E³.}

1Department of Fisheries and Aquatic Environment Rivers State University of Science and Technology, P.M.B. 5080, Port Harcourt, Nigeria.

${ }^{2}$ African Regional Aquaculture Centre/Nigeria Institute for Oceanography and Marine Research, P.M. B. 5122, Port Harcourt Nigeria.

3Department of Applied and Environmental Biology, Faculty of Science, Rivers State University of Science and Technology, P.M.B. 5080 Port Harcourt, Rivers State, Nigeria. *ojoakinrotimi@yahoo.com

\begin{abstract}
Haematological characteristics of Anadara senilis was investigated. A total of two hundred and forty (240) were sampled from Andoni flats during low tide. They were immediately transferred to the laboratory, where they were sorted and grouped into four different sizes. Group one comprised of (mean length $2.54 \mathrm{~cm} \pm 2.42$ and mean weight of $8.37 \mathrm{~g} \pm 2.44$ ); size group two has (mean length $3.84 \mathrm{~cm} \pm 0.42$ and mean weight 21.42) while group three has $(5.76 \mathrm{~cm} \pm 0.38$ and mean weight of $36.17 \mathrm{~g} \pm 3.55)$ and group four has mean length $(7.89 \mathrm{~cm} \pm$ 0.32 ; mean weight of $57.41 \mathrm{~g} \pm 6.81$ ). Blood was then taken from the bivalves and were later analysed in the laboratory. The mean values of haematological profiles recorded were (mean \pm S.D), haemoglobin (Hb) $4.08 \pm 1.88 \mathrm{~g} \mathrm{dl}-1$; Packed Cell Volume (PCV) $10.98 \pm 6.79 \%$; Red Blood Cells (RBC) $1.97 \pm 0.68 \times 10^{12}$ cells $\mathrm{I}^{-1}$; White Blood Cells (WBC) $3.76 \pm 1.51 \times 10^{9}$ cells L $^{-1}$ Platelets (PLT) $75.36 \pm 88.36 \%$; Mean Corpuscular Haemoglobin (MCH) $20.06 \pm 3.98 p g$; Mean Corpuscular Volume (MCV) $50.64 \pm$ 19.30FI; Mean Corpuscular Haemoglobin (MCHC) $43.79 \pm 13.71 \mathrm{gdll}^{-1}$; Oxygen Carrying Capacity (OCC) $6.11 \pm$ $2.83 \mathrm{vol}$. \%. The highest range of the parameters was recorded in platelets, while the lowest was observed in RBC. Significant differences $(P<0.05)$ were observed between the four size groups in all the parameters studied. It appeared from the trials that the quantity and quality of the blood tends to increase with size.
\end{abstract}

Key words: Haematology, Bloody cockle, size, Andoni flats, Niger Delta.

\section{INTRODUCTION}

The bivalve Anadara senilis is one of about 200 species in the family Arcidae often called bloody cockles, which inhabits softbottom intertidal area in tropical to warm temperate waters around the globe (Mzighani, 2005). They occur in most West African estuaries and lagoons, are naturally endemic to West Africa Coastal regions from Senegal in the north, to Angola in the South. (Afinowi, 1975). In Rivers State Nigeria, the bivalve, Anadara senillis occurs in the upper reaches of the Andoni flats and at the mouth of the New Calabar and Bonny Rivers around Mbiaka, Finima, Elem Ifoko and other coastal towns (Dekae, 1985). The author reported that the distribution appeared to be limited by salinity (18-27ppt) and sediment type (low intertidal sand or sandy and deposits). The salinity range (17-22ppt) and sediment type of the axis of the Andoni Flats where the bivalve occurs fall within this range (Francis et al., 2007).

The saline swamp or mangrove zone in Nigeria where these bivalves are found is estimated to be about 1 million hectares (Ekundayo, 1985). According to Deekae et al., (1994), this large area can be utilized for the culture of the mangrove mollusks. As the culture of mollusks is already a viable industry in Asia (Pillay 1972; Broom, 1985) and Europe (Chew, 1986; Salin et al., 1999). Despite the vast resources and potential that abounds in Nigeria, and other developing countries, the culture of mangrove molluscs has not been explored. In the parts of Andoni Flats where $S$. senilis occurs, the seeds are collected from the wild and extensively cultured in more secure locations, until they attain larger sizes when they are harvested. The only available report on the trial culture in some coastal towns of Rivers State is that of Aleem (1986), where $75 \%$ survival and a yield of $91.6 \mathrm{~kg} / \mathrm{m}^{2}$ were reported.

With the rise in the population of Nigeria and other developing nations, there is need to increase food production to meet this challenge and one of the ways of achieving this goal is the rearing of shell fishes especially bivalve species which are source of cheap animal protein, and are considered a delicacy among many (Mgaya et al., 1999; Ansa \& Sikoki, 2006). They generally live in relatively accessible habitats and its harvesting often requires no equipment or capital investment, as a result the specie are easily taken up by coastal villagers mostly women and children living around these environment, thereby subjecting this bivalve to intense harvesting and over exploitation. Hence, this necessitates the need to culture $S$. senilis in commercial quantities.

However, one of the main problems in tropical regions in culturing of $A$. senilis is the lack of information on its basic biology, physiology and health status of this bivalve, which can help in its effective management. One of the difficulties in assessing the state of health of natural fish population has been the paucity of reliable references of its normal condition. In pursuant to this goal, many fish biologists have turned to studies of haematology, probably because it has proved a valuable diagnostic tool in evaluating human health; hence fish haematology continues to offer the potential of a valuable tool (Kori-Siakpere et al., 2005). Haematological studies in fishes have assumed a greater dimension due to the increasing emphasis on aquaculture and greater awareness of the pollution of natural freshwater resources in the tropics. Such studies have generally been used as an effective and sensitive index to monitor environmental physiological, pathological and biochemical changes in fishes (Iwama et al., 1976; Gabriel et al., 2007b; Akinrotimi et al., 2007). Haematological characteristics, therefore, is the establishment of base line values of haematological parameters of fish which will serve as a reference standard, for a particular species in a locality with acceptable limits (Gabriel et al.,; 2004, Akinrotimi et al., 2009). According to Babatunde et al., (1992), any changes in the constituent component of blood sample when compared to the blood profile could be used to interpret the metabolic and health status of the animal.

There are no reports, whatsoever on the haematological characteristics of Anadara senilis, in Andoni flats, Niger Delta. Hence, the need to undertake the present study to establish a haematological profiles of this specie so as to provide some useful information on this aspect of its biology and provide basis for future comparative analysis.

\section{MATERIALS AND METHODS}

Sample collection: Over 1,000 Anadara (Senilia) senilis were collected from Adoni area, located in the intertidal zone of the 
Andoni flats, Rivers State Niger Delta, Nigeria (latitudes $4^{0} 28^{\prime}$ to $4^{\circ}$ $45 \mathrm{~N}$ and longitude $7^{0} 22^{\prime}$ to $\left.70-23^{\prime}\right)$. This area is a brackish water environment, with tidal regimes mangrove trees, and a diversity of fin and shell fishes. After collection from the field, they were rinsed in water and transferred to Department of Fisheries Laboratory, at Rivers State University of Science and Technology, Port Harcourt Rivers State where they were sorted into four different groups based on shell width size.

The Shell width, were measure with a pair of Venire calipers, while the weight was determined with a sensitive weighing balance (santod USA model). Blood were collected from two hundred and forty (240) bivalves with 60 from each size group. Blood samples were obtained with heparinized plastic syringe, fitted with 21 gauge hypodermic needle and preserve in disodium salt of Ethylene Diamine Tetraacetic Acid (EDTA) bottles for analysis.

Standard haematological procedures described by Brown (1980) were employed in the assessment of the various blood parameters. Haemoglobin $(\mathrm{Hb})$ was done by the cyano methaemoglobin method, Packed Cell Volume (PCV) by microhaematocrit method. Thrombocytes (thrmb) was determined by micro-Wintrobe method. WBC was determined with the improved Neubauer counter, differential counts was done on blood film stained with May-Grumwald-Giemsa stain, RBC was estimated using the relationship between $\mathrm{Hb}$ and PCV (Miale, 1982). Mean corpuscular Haemoglobin Concentration (MCHC), Mean Corpuscular Volume (MCV) and Mean Corpuscular
Heamoglobin (MCH) were calculated according to Brown (1980). Leucocrit was done according to Wedemeyer et al., (1983), while oxygen carrying capacity of the fish blood was calculated by multiplying the haemoglobin content by 1.25 , oxygen combining power of $\mathrm{Hb} / \mathrm{g}$ (Johansen, 1970).

Data obtained from the experimental fish were analysed using the General Linear Model (GLM) of ANOVA, and multiple range test at $0.05 \%$ probability, differences among means where existed were separated using Tukey's multiple comparison test.

\section{RESULTS}

The bivalves used for the experiment were classified into four size class using their length as follows: group $1(1.0-3.00 \mathrm{~cm})$, group $2(3.01$ to $5.00 \mathrm{~cm})$, group $3(5.01$ to $7.00 \mathrm{~cm})$ and group $4(7$ to $9.00 \mathrm{~cm})$. The haematological profiles of $S$. senilis in the various size groups (Table 1) indicated that in most of the parameters the values tends to increase with size. During blood sampling the bigger size appeared to have more quantity of blood than the smaller ones, based on the ease of collection with the syringe.

The mean values of pooled data (Table 2) for all the size groups shows that the highest values were observed in platelets with the value of $(175.36 \pm 88.36)$, while the lowest values of $(1.97 \pm 0.68)$ was obtained. Pearson's correlation (Table 3 ) indicated significant physiological interaction between size lengths are weight and all the blood parameter under investigation.

TABLE 1: HAEMATOLOGICAL CHARACTERISTICS OF BLOODY COCKLE Anadara senilis IN VARIOUS SIZE GROUP

\begin{tabular}{|c|c|c|c|c|c|c|c|c|c|c|c|c|}
\hline \multirow{2}{*}{ Parameters } & \multicolumn{3}{|c|}{ Size Group 1} & \multicolumn{3}{|c|}{ Size Group 2} & \multicolumn{3}{|c|}{ Size Group 3} & \multicolumn{3}{|c|}{ Size Group 4} \\
\hline & *Mean & Min & Max & ${ }^{*}$ Mean & Min & Max & *Mean & Min & $\operatorname{Max}$ & *Mean & Min & Max \\
\hline $\mathrm{Hb}$ & $2.00 \pm 0.01^{a}$ & 2.00 & 2.06 & $2.93 \pm 0.69 \mathrm{~b}$ & 2.00 & 4.00 & $4.79 \pm 0.11^{c}$ & 3.50 & 6.00 & $6.62 \pm 0.59 d$ & 5.50 & 7.20 \\
\hline RBC & $1.00 \pm 0.01^{\mathrm{a}}$ & 1.00 & 1.00 & $1.87 \pm 0.43^{b}$ & 1.20 & 2.41 & $2.39 \pm 0.17 \mathrm{c}$ & 2.10 & 2.70 & $2.66 \pm 0.11^{d}$ & 2.50 & 2.90 \\
\hline PCV & $3.46 \pm 0.72^{\mathrm{a}}$ & 3.00 & 5.00 & $6.08 \pm 0.72^{b}$ & 5.00 & 7.01 & $14.54 \pm 2.14 c$ & 12.00 & 18 & $20.04 \pm 1.70^{d}$ & 17.00 & 22.10 \\
\hline WBC & $6.02 \pm 0.91^{a}$ & 4.50 & 7.50 & $3.58 \pm .76^{b}$ & 2.60 & 4.61 & $2.94 \pm 0.36^{c}$ & 2.20 & 3.40 & $2.48 \pm 0.27^{d}$ & 2.21 & 3.01 \\
\hline PLT & $46.72 \pm 11.06^{a}$ & 25.00 & 60.00 & $67.34 \pm 5.81^{b}$ & 60.00 & 77.00 & $71.20 \pm 5.39 b$ & 62.00 & 76.00 & $86.12 \pm 10.14 c$ & 75.12 & 90.16 \\
\hline $\mathrm{MCH}$ & $20.00 \pm 0.01^{a}$ & 20.00 & 20.00 & $16.23 \pm 2.78^{b}$ & 13.60 & 22.12 & $19.02 \pm 3.09 c$ & 15.20 & 24.00 & $25.00 \pm 0.32^{d}$ & 20.4 & 26.9 \\
\hline $\mathrm{MCHC}$ & $59.89 \pm 10.18^{c}$ & 40.00 & 66.68 & $48.73 \pm 11.43^{b}$ & 33.33 & 62.54 & $33.16 \pm 2.21^{a}$ & 29.17 & 35.38 & $33.14 \pm 0.63^{a}$ & 31.71 & 34.00 \\
\hline MCV & $33.93 \pm 8.02^{a}$ & 20.00 & 50.00 & $35.31 \pm 10.26^{a}$ & 21.70 & 50.10 & $57.32 \pm 7.43^{b}$ & 49.90 & 72.00 & $76.27 \pm 6.93^{c}$ & 63.00 & 82.51 \\
\hline $\mathrm{OCC}$ & $3.00 \pm 0.01^{\mathrm{a}}$ & 3.00 & 3.00 & $4.40 \pm 1.03$ & 3.00 & 6.00 & $7.18 \pm 1.31^{c}$ & 5.31 & 9.01 & $9.93 \pm 0.88^{d}$ & 8.36 & 10.88 \\
\hline
\end{tabular}

Table 2: STATISTICS OF HAEMATOLOGICAL PROFILE OF BLOODY COCKLE FROM ANDONI FLATS, NIGER DELTA. NIGERIA

\begin{tabular}{|c|c|c|c|c|c|c|c|c|c|c|c|}
\hline \multirow[b]{2}{*}{ Statistic } & \multicolumn{11}{|c|}{ Variables } \\
\hline & $\begin{array}{l}\text { Length } \\
\text { (cm) }\end{array}$ & $\begin{array}{l}\text { Weight } \\
\text { (g) }\end{array}$ & $\mathrm{Hb}$ & PCV & RBC & WBC & PLT & $\mathrm{MCH}$ & $\mathrm{MCHC}$ & MCV & OCC \\
\hline Mean & 3.85 & 27.42 & 3.84 & 10.32 & 1.75 & 4.38 & 169.72 & 21.10 & 46.63 & 5.76 & 50.23 \\
\hline Standard error & 0.90 & 1.35 & 0.13 & 0.47 & 0.50 & 0.12 & 12.96 & 0.20 & 0.98 & 0.20 & 1.24 \\
\hline Median & 3.58 & 14.62 & 2.0 & 5.00 & 0.05 & 4.50 & 60.00 & 20.00 & 66.67 & 3.00 & 30.00 \\
\hline Mode & 2.39 & 6.92 & 2.00 & 3.00 & 1.00 & 3.00 & 60.00 & 20.00 & 66.67 & 3.00 & 30.00 \\
\hline Standard deviation & 1.46 & 21.07 & 2.03 & 7.34 & 0.77 & 1.80 & 201.58 & 3.06 & 15.25 & 3.00 & 19.32 \\
\hline Skewness & 0.30 & 0.47 & 0.42 & 0.29 & 0.12 & 0.27 & -1.88 & 0.58 & 0.41 & 3.09 & 0.29 \\
\hline Kurtosis & -1.35 & 1.22 & -2.53 & -1.63 & -1.88 & -1.47 & -0.56 & -0.11 & -1.65 & 0.42 & -1.25 \\
\hline Minimum & 1.22 & 3.41 & 2.00 & 3.00 & 1.00 & 2.20 & 50.36 & 15.22 & 29.17 & -1.53 & 20.00 \\
\hline Maximum & 6.55 & 74.23 & 7.22 & 22.10 & 2.90 & 7.50 & 15.00 & 26.96 & 66.68 & 3.00 & 82.00 \\
\hline
\end{tabular}

$\mathrm{Hb}$ - Haemoglobin (gdL ${ }^{-1}$ ), PCV: Packed Cell Volume (\%), WBC - White Blood count (cells x $\left.10^{9} \mathrm{cells} \mathrm{L}^{-}\right)$, RBC - Red Blood Cells (Cells $\times 10^{12} \mathrm{~L}^{-1}$ )

PLT - Platelets $(108 / \mu \mathrm{L}), \mathrm{MCH}$ - Mean Corpuscular; Haemoglobin $(\mathrm{pg}), \mathrm{MCHC}$ : Mean Corpuscular Haemoglobin Concentration (gdL-1)

MCV - Mean Corpuscular Vol. (FI), OCC - Oxygen Carrying Capacity (Vol. \%),

*Means within the row with different super script are significant $(P<0.05)$. 
TABLE 3. INTRA SPECIES HAEMATOLOGICAL RELATIONSHIP IN S. senilis

\begin{tabular}{|c|c|c|c|c|c|c|c|c|c|c|c|}
\hline & \multicolumn{11}{|c|}{ Correlation coefficients } \\
\hline & Size & Length & Weight & $\mathrm{Hb}$ & PCV & RBC & WBC & PLT & $\mathrm{MCH}$ & $\mathrm{MCHC}$ & MCV \\
\hline Size & & & & & & & & & & & \\
\hline Length & 0.949 & & & & & & & & & & \\
\hline Weight & 0.946 & 0.976 ** & & & & & & & & & \\
\hline $\mathrm{Hb}$ & $0.935^{\star \star}$ & 0.898 ** & 0.902 ** & & & & & & & & \\
\hline PCV & $0.960 * *$ & $0.912^{\star \star}$ & 0.920 ** & $0.971^{*}$ & & & & & & & \\
\hline RBC & $0.911 * *$ & $0.857^{\star *}$ & 0.844 ** & $0.879 *$ & 0.858 & & & & & & \\
\hline WBC & $-0.837^{\star \star}$ & $-0.780 * \star$ & -0.764 ** & -0.703 & -0.735 & -0.784 & & & & & \\
\hline PLT & $0.798 * *$ & $0.813^{\star *}$ & $0.822^{\star *}$ & 0.791 & 0.784 & 0.624 & -0.520 & & & & \\
\hline $\mathrm{MCH}$ & $0.498^{\star *}$ & $0.514^{\star \star}$ & 0.536 ** & 0.680 & 0.650 & 0.313 & -0.180 & 0.697 & & & \\
\hline $\mathrm{MCHC}$ & $-0.785^{\star \star}$ & $-0.718^{\star *}$ & -0.716 ** & -0.646 & -0.775 & -0.655 & 0.721 & -0.474 & -0.237 & & \\
\hline MCV & $0.865^{\star \star}$ & $0.829 * *$ & 0.839 ** & 0.872 & 0.935 & 0.672 & -0.643 & 0.773 & $0.747^{*}$ & -0.808 & \\
\hline OCC & $0.935^{\star \star}$ & $0.898^{\star *}$ & 0.903 ** & $1.000^{*}$ & 0.971 & $0.879 x$ & -0.703 & 0.791 & 0.686 & -0.646 & 0.872 \\
\hline
\end{tabular}

$\mathrm{Hb}$ - Haemoglobin (gdL $\mathrm{g}^{-1}$ ), PCV: Packed Cell Volume (\%), WBC - White Blood count (cells x $10^{9}$ cells L-), RBC - Red Blood Cells (Cells x 1012 $\mathrm{L}^{-1}$ ) PLT - Platelets $\left(10^{8} / \mu \mathrm{L}\right), \mathrm{MCH}$ - Mean Corpuscular; Haemoglobin $(\mathrm{pg}), \mathrm{MCHC}$ : Mean Corpuscular Haemoglobin Concentration (gdL-1) MCV - Mean Corpuscular VoL. (FI), OCC - Oxygen Carrying Capacity (Vol. \%),

${ }^{*}$ Correlation is significant at the 0.05 level

** Correlation is significant at the 0.01 level

\section{DISCUSSION}

The haematological characteristics of some culturable fish species have been investigated with the aim of establishing normal blood values, ranges with respect to sex, age, size environmental and physiological conditions (Kori-Siakpere, 1985; Sowunmi, 2003; Gabriel et al., 2007a). According to Akinrotimi et al., (2009) size of a fish is a very crucial factor in establishment of fish haematological profiles. The significant differences $(P<0.05)$ observed in almost all the blood parameters between the four size groups, of the bivalves is in agreement with the findings of KoriSiakpere \& Egor (1997) who observe the influence of size on Clarias buthupogun, which increased with size.

The general trend in the relationship between blood parameters and body size is that the bigger the fish, the higher the values of its haematological parameters. For example, Jawad et al., (2004), found that the values of $\mathrm{Hb}, \mathrm{RBC}$ and PCV increased as the fish size increase. Similar result were obtained for Clarias batrachus (Jushi \& Tardon, 1977), Tilapia zilli (Ezzat et al., 1973), Cyprinus Carpio, bivalve Barlatia reevena (Grinich \& Terwilliger, 1980) and Amphiprous cuchia (Banerjee, 1986). It should be noted that the differences recorded in blood parameters between various sizes according to Paizada et al., (1983), are genetically determined, but Chaudhuri et al., (1986) suggested that the difference might be due to the higher metabolic rate, of the bigger fish compared to smaller ones. Our results support this suggestion which has been related to an increase in fish activity with an increase in size. This is because different rates of bivalve activity demand different levels of metabolic activity and these activities require several physiological adjustments which involve haematological parameters.

The haemoglobin, concentration values recorded in study are comparable to those reported for burrowing brittle star Henipholis enlongata and Barbatia reeveena (Grinich \& Tervullige, 1980), while the $(P C V)$ is similar to the

observations of Dueler et al., (1983) in bivalve Solemya velum, an indication that these bivalves required high concentration of oxygen as a result their burrowing activities

The correlation coefficient among haematoligical parameters and size of $A$. senilis, indicated that size have influence on its haematological parameters, a position that has been supported by
Sowumi (2003) and Kori-Siakpere (2005) in Clairias gariepinus and Parachanna obscura respectively.

\section{CONCLUSION}

The culture of Bloody cockle in the country is still at its infancy. This work will serve as a guide to aquaculturists on how to manage the health conditions of this bivalves for optimum production in culture medium.

\section{REFERENCES}

Afinowi, M. A. (1975). The biology of Anadara senilis and Oyster (Crassotrea gasar) in West Africa waters. Report on the symposium on aquaculture in Africa, Accra, Ghana. FAO, CIFA, TAPP 2:386-400.

Akinrotimi, O. A., Gabriel U. U.; Anyanwu, P. E. \& Anyanwu, A. O. (2007). Influence of sex, Acclimation methods and period on haematology of Sarotherodon melanotheron (cichlidae). Research Journal of Biological Sciences 2(3): 348-352.

Aleem, (1986). Culture trial of Bloody cockle Anadara senilis in Buguma fish farm. Nigerian Institute for Oceanography 1986 Annual Report.

Ansa, E. J. \& Sikoki , F. D. (2006). Composition distribution and abundance of benthic macro fauna in the Andoni flats, Niger Delta, Nigeria. Environment and Ecololgy 24(4): 784 - 790.

Babatunde, G. M.; Fajimi, A. O. \& Oyejide, A. O. (1992). Rubber seed oil versus palm oil in broiler chicken diet. Effect on performance nutrient, digestibility, haematology and carcass characteristics. Animal Feed Science Technology 35:133-146.

Banerjee, V. (1986). Haematology of the fresh water eel, Amphipnous cuchia (Hamilton): Erythrocyte dimensions with special reference to body length, Sex and Season. Comparative Physiology and Ecology, 2(2).68-73.

Brown, B. A. (1980). Haematology. Principles and procedure (3rd edn.) Lea and Fabiger, Philadelphia.

Chaudhuri, S. H. Pandit, T. \& Benerjee, S. (1986). Size and sex related variations of some blood parameters of sarotheriodon massambica. Environment and Ecology 4(1):61-63. 
Chew, K. K. (1986). Review of recent molluscan culture. World Conference on Aquaculture. Venice, Italy (1981). European Mariculture Society. 10:173-175.

Deekae, S. N.; Ayinla O. A. \& Marioghae, I. E. (1994). Possibilities of the culture of mangrove mollusks with special reference to the Niger Delta Nigerian Institute for Oceanography and Marine Research, Tech. Pap No.96 20pp.

Ekundayo, J. A. (1985). The challenges of the mangrove ecosystem. In Powell C. B. and Wilcox, H.B. R. (Ed.) The mangrove Ecxosystem of the Niger Delta. Publications committee, University of Port Harcourt. 203-211.

Ezzat, A. A. Shabana, M. B \& Faraghally, A. M. (1973). Studies on the blood characteristic of Tilapia zilli Blood cells. Journal of Fish Biology 6:1-12.

Francis, A., Sikoki, F.D. \& Ansa, E. J. (2007). Physico-chemical parameters of the Andoni River System. Niger Delta, Nigeria. Journal of Fisheries International 2(1) 27-31.

Gabriel, U. U., Ezeri, G. N. O. \& Opabunmi,O. O. (2004). Influence of sex, source, Health status and acclimation on the Haematology of Clarias gariepinus African Journal Biotechnology 3:463-437.

Gabriel, U. U.; Anyanwu, P. E. \& Akinrotimi, O. A. (2007a). Blood characteristics Associated with confinement stress in Black chin Tilapia, Sarotherodon melanotheron Journal of Fisheries International, 2(2): 186-189.

Gabriel, U. U.; Anyanwu, P. E. Akinrotimi, A. O. (2007b). Haematological Profile of Black-Chinned tilapia (Sarotherodon Melanotheron). Agricultural Journal 2(3): 384-387.

Grinich, N. P. \& Terwilliger, R. C. (1980). The Quaternary structure of an unusual high-molecular weight. Intracellular Haemoglobin from the Bivalve Mollusks Barbatia reeveana. Biochemical Journal 189:1-8.

Iwama G. K.; Greer G. L., Larkin D. A. (1976). Changes in some haematological characteristics of Coho salmon In response to acute exposure to dehydroabietics acid (DHAA) at different exercise levels. Journal of fisheries Research 33:285-289.

Jawad, L. A.; Al-Mukhtar, M. A. \& Ahmed, H. K. (2004). The relationship between haematocrit and some biological parameters of the Indian Shad, Tenualosa ilisha (Family clupidae). Animal Bioderversity 27(2) 47-52.
Johansen, K. (1970). Air-breathing fishes. In: Hoar, W. S. and D. T. Rendall (eds). Fish phy. Acad. Press, New York, London.

Kori-Siakpere, O., Egor, V. E. (1997). Haematological characteristics of the African Mudfish: Clarias buthupogon (clariidae). Bulletin of Science Association of Nigeria. 21:177-185.

Kori-Siakpere, O. (1985). Haematological characteristic of Clarias isheriensis sydenham. Journal of Fish Biology 27:259-263.

Kori-Siakpere, O.; Ake, J. E. G, \& Idoye, E. (2005). Haematological Characteristics of the African snake head, Parachanna obscura. African Journal of Biotechnology 4(6):527-530.

Mgaya, Y. D. Muruki, M. H.S. \& Semesi, A. K. (1999). The sea cucumber and mollusic fisheries in Bagamony Tanzania. West Indian Ocean Journal of Marine Science. 1(2):100-112.

Miale, J. B. (1982). Laboratory medicine haematology (6th Edn.) The C. V. Mosby Co., London, 883 pp.

Mzighani, S. (2005). Fecundity and population structure of cockles Anadara antiquates L. 1758 (Bivaluia: Arcidae) from a sandy muddy Beach near Dares salem, West Indian Ocean. Journal of Marine Science 4(1): 77-84.

Pillay, T. V. R. (1972). Coastal aquaculture in the Indo Pacific Region. Fishing news (Books) Ltd. Survey.

Quayle, D. 1980. Tropical Oysters culture and methods International development research centre, Ottawa, Canada, IDRC - TS 17e.

Salin, C.; Dyzgunes E.; Mutlu C.; Aydin M. \& Emiral, H. (1999). Determination of the growth parameters of the Anadara cornea population by the Bhatta charya method in the Eastern Blacksea Tr. Journal of Zoology. 23:99-105.

Sowunmi, A. A. (2003). Haematology of the African catfish, Clarias gariepinus (Burchell, 1812). From Eleyele Reservoir Ibadan, Southwest Nigeria. The Zoologist 2(1):85-91.

Wedemeyer, G. A., R. W. Gould \& Yasutake, W. T. (1983). Some potentials and limits of the leucocratic test as fish health assessment method. Journal of Fish Biology, 23:711-716. 